\title{
Evaluating the Performance of Small-Scale Irrigation Schemes in Sub Humid Ethiopian Highlands; a case study in Mugie and Fesas
}

Agmasie M. Belay

South Gondar Zone Agricultural Directive

Tewodros Assefa ( $\square$ ttaffese@gmail.com)

Bahir Dar University

Sisay A. Belay

Bahir Dar University

Abdu Y. Yimam

Bahir Dar University

\section{Research}

Keywords: Irrigation scheme performance, Small-scale irrigation, Sub-humid Ethiopian highlands

Posted Date: February 28th, 2022

DOI: https://doi.org/10.21203/rs.3.rs-1303002/v1

License: (c) (1) This work is licensed under a Creative Commons Attribution 4.0 International License.

Read Full License 


\section{Abstract \\ Background}

This study was conducted to evaluate the performance of two small-scale irrigation (SSI) schemes in the sub-humid Ethiopian highlands. Water application at the farm level was monitored using partial flume and the average flow velocity along the main canal was measured using the current meter. The infiltration measurement was conducted at the head, middle, and tail of the scheme within the command area using a double-ring infiltrometer. Soil samples were collected using an auger up to $60 \mathrm{~cm}$ depth. Climatic and agronomic data were collected from the nearby meteorological station and woreda agricultural office, respectively. CROPWAT was used to determine the water requirement of crops.

\section{Results}

The result showed that the average conveyance efficiency for the lined main canal was $90 \%$ and $92 \%$ for Mugie and Fesas SSI, respectively. The conveyance efficiency for the unlined main canal was in the order of $86 \%$ and $87 \%$ for Mugie and Fesas SSI. On the other hand, the average application efficiency and overall efficiency were found to be $56 \%$ and $51 \%$, respectively, with storage efficiency of $50 \%$ for Mugie irrigation scheme. Similarly, the overall, application and storage efficiencies were found $50 \%, 54 \%$, and $56 \%$, respectively, for Fesas irrigation scheme. The relative irrigation and water supplies were 1.23 and 3.17, respectively, for Mugie SSI, while the supplies were 0.94 and 2.45, respectively, for Fesas SSI.

\section{Conclusions}

Conveyance efficiency for both Mugie and Fesas schemes was found below standard (95\%) and overall efficacy was low as well ( 50\%). Failure of operating gates in the main canal, overtopping of water from the main canal due to canal siltation, and leakage through the main canals were the main causes for poor performance. Improvement measures are needed for both Mugie and Fesas irrigation schemes and institutional support is vital to improve and maintain the failure of infrastructures for better performance.

\section{Introduction}

Ethiopia is an agrarian nation where 80 to $85 \%$ of the population is engaged in subsistent agriculture such as crop and livestock production (Abraham, 2009; Asmamaw, 2015; Eggen et al., 2016; Gebru, 2016). The agricultural practice is mainly rainfed systems (Kortenhorst et al., 1989; Makombe et al., 2017; Ngigi, 2003) with traditional tillage using animals and hand tools. However, rainfed agriculture greatly suffers from uneven and erratic rainfall distribution resulting in crop failure and production loss (Abiyu, 2016; Boke, 2017; Bossio et al., 2012; Gebresenbet, 2015).

Irrigation has contributed significantly to poverty reduction, food security, and improving the quality of life especially for the rural population (Alemu, 2017; Gebregziabher et al., 2009). Awulachew and Ayana, 
(2011) reported that the potential of irrigable land in Ethiopia is around 6 million hectares (Mha). From these potential land resources, around 4 Mha could be developed using surface water sources, and 2 Mha using groundwater and rainwater management according to the study. In Ethiopia, irrigation projects have been built to boost dry season food production through government interventions from surface water sources.

Small-scale irrigation (SSI) has been promoted in Ethiopia to solve the problem of food shortage and improve the livelihood of smallholder farmers with various capacities and scales (Adela et al., 2019; Amede, 2015; Xie et al., 2021; Zeweld et al., 2015, Aseyehegu et al., 2012; Tesfaye et al., 2008). According to Hagos et al.,(2011), around $4.5 \%$ of the agricultural gross domestic product (GDP) and $2 \%$ of the total overall GDP of the nation was gained through irrigated agriculture with more than twice the income generation for the smallholder farmers. Beyond the wide benefit of SSI, leakage problems in the main canals, quality of scheme design, lack of institutional support for regular maintenance of scheme, lack of market access, poor agronomic and water management practices, and excessive siltation along the canals, all together, constrained the performance of irrigation schemes (Awulachew and Ayana, 2011).

The performance of small-scale irrigation schemes was studied in the Ethiopian highlands. Mostly the performance assessment was reported considering conveyance and application efficiency from the internal indicators. Physical performance was mostly reported from the external indicators. However, the level of scheme performance is not only dependent on conveyance and application losses but rather various performance indicators also need to be considered. Besides, the performance of the scheme against the challenges of the SSI has not been well studied considering possible indicators are lacking in the sub-humid Ethiopian highlands. This requires a detailed performance assessment throughout the irrigation infrastructures starting from the headwork up to the command area. Therefore, the objective of this study is to assess and evaluate the performance of two small-scale irrigation schemes using various performance indicators. The result from this study provides reliable evidence for decision-makers and local stakeholders for remedial action to improve the productivity of small-scale irrigation schemes and consequently improve the livelihood of smallholder farmers.

\section{Materials And Methods \\ 2.1 Study area}

This study was conducted in Mugie and Fesas's small-scale irrigation schemes found in the sub-humid Ethiopian highlands (Figure 1). Geographically, the Mugie scheme is found at $11.42^{\circ} \mathrm{N}, 38.25^{\circ} \mathrm{E}$ and 2472 meters above mean sea level (AMSL), whereas, Fesas scheme is found at $11.44^{\circ} \mathrm{N}, 38.19^{\circ} \mathrm{E}$, and 2395 meters AMSL. The command area covers $82 \mathrm{ha}$ for Mugie and $75 \mathrm{~h}$ a for Fesas irrigation schemes. The area receives an annual rainfall of about $1500 \mathrm{~mm}$ having a minimum and maximum temperature of $7.50 \mathrm{c}$ and 31oc, respectively (Kindu, 2019). The schemes were designed to enhance crop production twice a year for the community; the first irrigation season from October to February and the second irrigation season from February to June each year. The major crops irrigated along the command area were maize, onion, potato, 
and tomato. Clay is the dominating soil type for both the irrigation schemes (i.e., Mugie and Fesas) from laboratory analysis of soil samples. On the other hand, agricultural land, grazing land, forest land, and residential areas are the mainland uses observed during the period of the study. The irrigation schemes were designed to provide service for about 120 and 80 farmers in Mugie and Fesas irrigation schemes, respectively.

\subsection{Method of data collection}

This research was carried out during the dry season irrigation period (October 2019 to June 2020). Field data such as soil samples, farm-level irrigation water application for each irrigation scheme were monitored at 3 convenient locations (head, middle and tail end) across the irrigation schemes in the command area. A total of 54 soil samples were collected from 3 different depths using auger: 0 to $20 \mathrm{~cm}$, 20 to $40 \mathrm{~cm}$, and 40 to $60 \mathrm{~cm}$ considering the maximum rooting depth of irrigated crops. The soil samples were analyzed for soil texture, bulk density, field capacity, and permanent wilting point in the Debre Tabor University soil laboratory. The depth of water applied at the field level was measured using partial flume at the initial, developmental, and late stages of the crop growth (Figure 2). Flow velocity was measured 3 times per cropping season using a current meter (Figure 2) in the main canals. Soil infiltration rates were recorded using a double-ring infiltrometer at the head, middle, and tail of the command area. The length of canals and area of field plots were measured with a tape meter. Climatic data such as maximum and minimum temperature, relative humidity, sunshine hour, rainfall, and wind speed were obtained from the nearby Estie meteorological station (Table 1). Various agronomic data including crop yield, irrigated area per crop season, production cost per season, and income generated by the irrigation associations were collected from the office of the agricultural bureau (i.e., Simada Woreda). 
Climatic parameters and average daily evapotranspiration

\begin{tabular}{|lllllll|}
\hline Month & Tmax (oc) & Tmin (oc) & T. average (oc) & Rainfall (mm) & Ave. RH (\%) & Ave. ETo (mm) \\
\hline Sept. & 20.4 & 9.4 & 14.9 & 194.5 & 75 & 2.64 \\
\hline Oct. & 21.5 & 8.7 & 15.1 & 74.3 & 65 & 2.34 \\
\hline Nov. & 22 & 8.1 & 15.05 & 28.7 & 60 & 1.72 \\
\hline Dec. & 21.6 & 7.5 & 14.55 & 11.9 & 56 & 1.27 \\
\hline Jan. & 22.1 & 7.6 & 14.85 & 7 & 52 & 1.84 \\
\hline Feb. & 24.5 & 9.2 & 16.85 & 5.6 & 49 & 2.69 \\
\hline Mar. & 24.9 & 10.4 & 17.65 & 34.4 & 47 & 3.55 \\
\hline Apr. & 24.8 & 10.9 & 17.85 & 46.1 & 47 & 4.16 \\
\hline May & 23.2 & 10.9 & 17.05 & 114.5 & 56 & 4.3 \\
\hline June & 22.1 & 10.5 & 16.3 & 164.5 & 70 & 3.84 \\
\hline Note: T, RH, and ETo are temperature, relative humidity, and reference evapotranspiration respectively. \\
\hline
\end{tabular}

\subsection{Crop water requirement}

The water requirement of irrigated crops was determined using the crop water assessment tool (CROPWAT) for the initial, development, and late stage of crop growth. In this method, the reference evapotranspiration was determined using the Penman-Monteith method. Effective rainfall was computed using the United States Department of Agriculture Soil Conservation (USDA S.C. method). Net irrigation requirement of crops was then computed as a difference between crop water requirement and effective rainfall.

\subsection{Selection and Evaluation of Performance Indicators}

The performance of irrigation schemes was evaluated based on various indicators. Various internal and external performance indicators were mentioned by Molden et al., (1998) to assess the performance of irrigation schemes. From the internal indicators storage, application, and conveyance efficiency were selected to evaluate the scheme performance (De Alwis and Wijesekera, 2011; Dessalew et al., 2016; Kartal et al., 2020). Similarly, agricultural, water supply, physical and financial performance indicators were selected from the external indicators based on Değirmenci et al., (2017), Agide Dejen (2012), Bumbudsanpharoke, and Prajamwong, (2015), and Al-Said et al., (2012).

Conveyance Efficiency $(\mathrm{Ec})$ refers to the volume of water lost by the network of conveyance canals due to seepage and evaporation (Kassa and Ayana, 2019) and is determined as shown in equation 1.

$E_{C}=\left(Q_{\text {out }} / Q_{\text {in }}\right) * 100$ (Eq. 1) 
Where, Ec, $Q_{i n}$, and $Q_{\text {out }}$ are conveyance efficiency (\%), inflow, and outflow discharge ( $\left.\mathrm{m}^{3} / \mathrm{sec}\right)$ in specified canal reach measured 3 times a month during the cropping season. The inflow and outflow discharge through the canal was determined as a product of the cross-sectional area with the average flow velocity. The current meter was used to determine the average flow velocity by counting the number of rotations of the propeller shaft as explained in Alebachew and Ing, (2018) using equation 2.

$V=k^{*} n+\otimes(E q .2)$

Where, $\mathrm{n}$ is the number of propeller rotations (i.e., revolution per second), $\mathrm{k}$, and $\Delta$ are constant values determined based on the number of propeller rotations (Table 2).

Table 2

Average velocity determination using a current meter (Alebachew and Ing, 2018)

\begin{tabular}{|lllll|}
\hline S.no & $\begin{array}{l}\text { Number of propeller rotation range } \\
(\mathbf{n})\end{array}$ & $\begin{array}{l}\text { Average Velocity } \\
(\mathbf{c m} / \mathbf{s e c})\end{array}$ & \multicolumn{2}{l}{$\begin{array}{l}\text { Coefficients (constant } \\
\text { values) }\end{array}$} \\
\cline { 3 - 5 } & & $\mathbf{k}$ & $\square$ \\
\hline 1 & {$[0,1.98]$} & $31.17 n+1.93$ & 31.17 & 1.93 \\
\hline 3 & {$[1.98,10.27]$} & $32.05 n+0.19$ & 32.05 & 0.19 \\
\hline $\begin{array}{l}\text { Note: } \mathrm{n} \text { is the number of propeller rotations. } \mathrm{k} \text { and } \mathrm{B} \text { are constant values estimated based on the } \\
\text { number of propeller rotation }\end{array}$ & $33.44 \mathrm{n}-14.09$ & 33.44 & -14.09 \\
\hline
\end{tabular}

Application Efficiency (Ea) refers to the ratio of the average depth of irrigation water infiltrated and stored in the plant root zone to the average depth of irrigation water applied (Amer and Amer, 2010; van Halsema et al., 2011) and expressed as a percentage as shown in equation 3.

$E_{a}=\left(W_{s} / W_{f}\right) * 100($ Eq. 3)

Where, Ea, Ws, and Wf are application efficiency (\%), the average depth of water stored in the plant root zone $(\mathrm{mm})$, and average water depth delivered to the field $(\mathrm{mm})$, respectively. The depth of water delivered to the field was recorded using a Parshall flume (Xiao et al., 2015) installed at the entrance of each field during irrigation. Soil moisture content before and after irrigation was determined by the gravimetric method (Fontenelli et al., 2017) to know the depth of water stored in the root zone by collecting soil samples from 0 to $60 \mathrm{~cm}$ depth with $20 \mathrm{~cm}$ depth increment.

Storage Efficiency (Es) relates the amount of water required by the plant with the amount of water stored in the root zone (Amer and Amer, 2010; van Halsema et al., 2011) and can be determined as shown in equation 4.

$E_{S}=\left(W_{S} / W_{n}\right) * 100$ (Eq. 4) 
Where, Es, Ws, and Wn are storage efficiency (\%), water stored in the root zone during irrigation, and water needed in the root zone before irrigation $(\mathrm{mm})$. The amount of water needed by the crop before irrigation depends on the type of soil and rooting depth (da Silva et al., 2017). It was estimated from the soil field capacity and permanent wilting point (Jabro et al., 2020) using equation 5.

$T A W=100 *\left(\square_{F C}-\square_{P W P}\right) * D_{r}$ (Eq. 5)

Where, TAW, $\triangle \mathrm{FC}, \triangle \mathrm{PWP}$ and $\mathrm{Dr}$ are volumetric total available water in the root zone $(\mathrm{mm})$, volumetric moisture content at field capacity $\left(\mathrm{m}^{3} / \mathrm{m}^{3}\right)$, volumetric moisture content at permanent wilting point $\left(\mathrm{m}^{3} / \mathrm{m}^{3}\right)$, and plant root depth $(\mathrm{m})$, respectively. According to Muluneh et al., (2017) the amount of water needed in the root zone before irrigation was taken as $75 \%$ of the total available water with a promising result of maximum crop productivity and used to determine the storage efficiency. The overall efficiency was computed as a product of conveyance and application efficiency to measure the performance of the irrigation schemes.

Agricultural performance indicators relate the value of production in dollar with the irrigated cropped area (ha), command area (ha), diverted and consumed irrigation water supply $\left(\mathrm{m}^{3}\right)$ as an output of the scheme (Değirmenci et al., 2017; Sener and Albut, 2011) and is determined by Equation 6.

' Output $=($ ProductionValue/ Irrigatedarea $)$

(ProductionValue/Commandarea)

(Productionvalue/ Irrigationsupply)

(Productionvalue/ Waterconsumption)

Where, the production value is the revenue in (\$) collected from crop production, irrigated area (ha) is the sum of areas covered by crops, command area (ha) is the design area to be irrigated, irrigation supply $\left(\mathrm{m}^{3}\right)$ is the volume of irrigation water diverted to the command area and water consumption is the amount of irrigation water consumed by the crops and evapotranspiration.

Water supply indicators. This indicator related the demand of crops with the amount of water supply to the field (Agide Dejen, 2012) according to equation 7. Two indicators were used to assess the performance of water supply namely; relative irrigation supply (RIS) and relative water supply (RWS).

$$
\left\{\begin{array}{c}
R W S=\text { Totalwatersupply / Cropwaterrequirement } \\
R I S=\text { Irrigationsupply/Irrigationrequirement }
\end{array}\right\} \text { (Eq. 7) }
$$

Where RWS and RIS are relative water supply and relative irrigation supply respectively. Total water supply is calculated as the volume of water diverted for irrigation plus rainfall $\left(\mathrm{m}^{3}\right)$.

Physical performance indicators evaluate the status of the command area coverage by irrigation. The irrigation ratio was selected (Bumbudsanpharoke and Prajamwong, 2015; Degirmenci et al., 2006) and 
determined using equation 8.

$I R=$ Irrigatedarea $/$ Commandarea (Eq. 8)

Where IR is irrigation ratio, irrigated area is an area (ha) covered by irrigation, and command area is mean to say the estimated total irrigable area (ha) during the design stage of the schemes.

Financial performance indicators compare the value of production from the irrigation schemes with the total cost of infrastructure (Al-Said et al., 2012) and were determined using equation 9.

GRI = Productionvalue/Infrastructurecost (Eq. 9)

Where GRI is the gross return on investment.

\section{Results And Discussion}

\subsection{Physical properties of soils}

The bulk densities of the soil varied from 1 to $1.2 \mathrm{gcm}^{-3}$, and 1.1 to $1.2 \mathrm{gcm}^{-3}$ at Mugie and Fesas SSI, respectively, which were clay-dominated in texture (Table 3). Imhoff et al., (2016) suggested a critical bulk density of $1.35 \mathrm{gcm}^{-3}$ as suitable for plant growth, indicating the suitability of both sites for plant growth. The average moisture content at field capacity at the head, middle, and tail was in the range of 26-38\% for the Mugie irrigation scheme while it was $26-37 \%$ for the Fesas irrigation scheme. The average moisture content of the soil at stressed condition, permanent wilting point (PWP), was found in the range of $14-17 \%$ for Mugie and $13-17 \%$ for Fesas irrigation schemes. The total available water holding capacity of soils was in the range of 120 to $250 \mathrm{~mm}$ for the Mugie irrigation scheme and 100 to $240 \mathrm{~mm}$ for Fesas irrigation schemes. An average steady-state infiltration capacity of $6 \mathrm{~mm} / \mathrm{hr}$ and $5.4 \mathrm{~mm} / \mathrm{hr}$ were obtained for Mugie and Fesas irrigation schemes respectively. According to Mahapatra et al., (2020), the soil is classified as low infiltration rate (i.e., infiltration rates less than $15 \mathrm{~mm} / \mathrm{hr}$ ). 
Table 3

Soil physical characteristics at Mugie and Fesas irrigation schemes

\section{Mugie Irrigation scheme}

Soil depth (cm)

\begin{tabular}{llllllllll} 
Sampling Location & Head & \multicolumn{3}{c}{ Middle } & \multicolumn{7}{c}{ Tail } \\
Soil Property & $0-20$ & $20-40$ & $40-60$ & $0-20$ & $20-40$ & $40-60$ & $0-20$ & $20-40$ & $40-60$ \\
\hline \% Sand & 27.7 & 30.7 & 26.7 & 33 & 28.7 & 29.0 & 30.7 & 28.3 & 29.0 \\
\hline \% Silt & 31.0 & 25.3 & 27.7 & 38.7 & 41.0 & 45.0 & 23.0 & 22.7 & 24.3 \\
\hline \% Clay & 41.3 & 44.0 & 45.7 & 28.3 & 30.3 & 26.0 & 46.3 & 49.0 & 46.7 \\
\hline $\begin{array}{l}\text { Bulk Density } \\
\text { (g/cm3) }\end{array}$ & 1.2 & 1.2 & 1.2 & 1.1 & 1.2 & 1.2 & 1.0 & 1.0 & 1.1 \\
\hline FC (\%) & 36.7 & 37.3 & 37.7 & 27.3 & 26.3 & 27.7 & 36.7 & 37.7 & 38.3 \\
\hline PWP (\%) & 14.3 & 15.0 & 14.7 & 15.4 & 14.1 & 15.9 & 14.0 & 17.3 & 17.0 \\
\hline TAW (mm) & 223.3 & 223.3 & 230.0 & 146.7 & 150.0 & 160.0 & 226.7 & 203.7 & 213.3
\end{tabular}

Fesas Irrigation scheme

\begin{tabular}{llllllllll} 
\% Sand & 33.7 & 28.3 & 27.3 & 26.7 & 29.3 & 27.7 & 25.7 & 24.3 & 23.7 \\
\hline \% Silt & 42.0 & 39.7 & 43.3 & 46.0 & 43.3 & 45.0 & 40.0 & 39.0 & 37.0 \\
\hline \% Clay & 26.7 & 32.0 & 29.3 & 27.3 & 27.3 & 27.3 & 34.3 & 36.0 & 36.0 \\
\hline $\begin{array}{l}\text { Bulk Density } \\
(\mathrm{g} / \mathrm{cm} 3)\end{array}$ & 1.1 & 1.2 & 1.1 & 1.2 & 1.2 & 1.2 & 1.2 & 1.2 & 1.2 \\
\hline FC (\%) & 25.6 & 28.0 & 26.3 & 37.3 & 35.7 & 33.7 & 27.0 & 30.3 & 30.7 \\
PWP (\%) & 14.1 & 13.0 & 11.0 & 17.3 & 16.0 & 16.7 & 13.7 & 14.3 & 13.0 \\
\hline TAW (mm) & 150.0 & 150.0 & 153.3 & 200.0 & 196.7 & 180.0 & 176.7 & 210.0 & 176.7
\end{tabular}

Note: FC, PWP, TAW, are field capacity, permanent wilting point, and total available water respectively.

\subsection{Water Requirement of Crops}

A total of 32.5 ha and 31.5 ha of land were covered with crops during the first irrigation season (October 2019 to February 2020) and second irrigation season (February to June 2020), respectively, at Mugie SSI. Whereas, a total of $26.8 \mathrm{ha}$ and 25.18 ha of land were covered with crops during the first and second cropping season, respectively, at Fesas SSI. The seasonal crop water requirement ranges from $323 \mathrm{~mm}$ (onion) to $338 \mathrm{~mm}$ (tomato) at Mugie, whereas it ranges from $240 \mathrm{~mm}$ (tomato) to $354 \mathrm{~mm}$ (onion) at Fesas SSI (Table 4). For Mugie irrigation schemes, $79497.5 \mathrm{~m}^{3}$ and $76949 \mathrm{~m}^{3}$ of irrigation water were needed for the first and second irrigation seasons respectively. Likewise, $63766.5 \mathrm{~m}^{3}$ and $62827.425 \mathrm{~m}^{3}$ 
irrigation water need was found for Fesas irrigation schemes in the first and second irrigation season respectively.

Table 4

Crop water requirement and net irrigation requirements of crops

\begin{tabular}{|c|c|c|c|c|c|c|}
\hline \multicolumn{7}{|c|}{ Mugie Irrigation Scheme } \\
\hline \multicolumn{4}{|l|}{ Season I } & \multicolumn{3}{|l|}{ Season II } \\
\hline Crops & Area(ha) & CWR (mm) & $\mathrm{NIR}(\mathrm{mm})$ & Area(ha) & CWR (mm) & $\mathrm{NIR}(\mathrm{mm})$ \\
\hline Tomato & 7.75 & 339 & 248 & 5.5 & 336 & 250 \\
\hline Maize & 6.75 & 336 & 232 & 8.5 & 332 & 231 \\
\hline Potato & 6.75 & 335 & 256 & 7.25 & 330 & 337 \\
\hline Onion & 11.25 & 323 & 243 & 10.3 & 340 & 320 \\
\hline Total & 32.5 & 1333 & 979 & 31.55 & 1338 & 1138 \\
\hline \multicolumn{7}{|c|}{ Fesas Irrigation Scheme } \\
\hline Tomato & 5.52 & 240 & 168 & 3.75 & 231 & 169 \\
\hline Maize & 4.69 & 232 & 161 & 6.01 & 237 & 164 \\
\hline Potato & 4.25 & 211 & 162 & 5.25 & 243 & 185 \\
\hline Onion & 12.36 & 354 & 267 & 10.17 & 323 & 243 \\
\hline Total & 26.82 & 1037 & 758 & 25.18 & 1034 & 761 \\
\hline
\end{tabular}

\subsection{Internal Performance Indicators}

The average conveyance efficiency at Mugie SSI was found $90 \%$ with a mean conveyance loss of 0.0424 $\mathrm{l} / \mathrm{sec} / \mathrm{m}$ for the lined main canal while it was $86 \%$ with conveyance loss of $0.13 \mathrm{l} / \mathrm{s} / \mathrm{m}$ for the unlined earth canal (Table 5). Similarly, for Fesas SSI, the average conveyance efficiency was found $92 \%$ with conveyance loss of $0.0421 \mathrm{l} / \mathrm{sec} / \mathrm{m}$ for the lined main canal while it was $87 \%$ with conveyance loss of $0.087 \mathrm{l} / \mathrm{sec} / \mathrm{m}$ for unlined earth canal. According to Akkuzu et al., (2007), the recommended value of conveyance efficiency and conveyance loss for the lined canal is $95 \%$ and $0.00031(\mathrm{l} / \mathrm{s} / \mathrm{m})$, respectively. The conveyance efficiency of both schemes was found below the recommendation for the lined canals. A range of permissible conveyance losses (i.e., 0.0017 to $0.005 \mathrm{l} / \mathrm{sec} / \mathrm{m}$ ) was reported with mean conveyance efficiency of $80 \%$ or unlined canals for clay loam soils by Wachyan and Rushton, (1987). Based on this, the conveyance loss through the unlined main canal of Mugie and Fesas irrigation scheme was found above the permissible range. A higher loss of water was observed in Mugie as compared to Fesas irrigation scheme. This situation was observed during field observation; physical observation of seepage, overtopping, sediment deposition, and boulder accumulation along the main canal of Mugie SSI 
(Figure 3). In this study, we found a lower conveyance efficiency as compared with other research findings in Ethiopia (Ahmed, 2017; Alebachew and Ing, 2018; Checkol and Alamirew, 2008) due to the nonfunctionality of the control gates, breaching of main canals, and illegal water diversion. 
Table 5

Computation of conveyance efficiency for the lined and unlined main canal.

\section{Mugie Irrigation Scheme}

\begin{tabular}{|c|c|c|c|c|c|c|c|c|}
\hline $\begin{array}{l}\text { Canal } \\
\text { Type }\end{array}$ & $\begin{array}{l}\text { Cropping } \\
\text { Season }\end{array}$ & $\begin{array}{l}\text { Test } \\
\text { ID }\end{array}$ & $\begin{array}{l}\mathrm{Pd} \\
(\mathrm{m})\end{array}$ & $\begin{array}{l}\text { Inflow } \\
\text { (I/sec) }\end{array}$ & $\begin{array}{l}\text { Outflow } \\
\text { (l/sec) }\end{array}$ & $\begin{array}{l}\mathrm{Cl} \\
(\mathrm{l} / \mathrm{sec})\end{array}$ & $\begin{array}{l}\mathrm{Cl} \\
(\mathrm{l} / \mathrm{sec} / \mathrm{m})\end{array}$ & $\begin{array}{l}\mathrm{Ce} \\
(\%)\end{array}$ \\
\hline \multirow{12}{*}{$\begin{array}{l}\text { Lined } \\
\text { Canal }\end{array}$} & \multirow[t]{6}{*}{ First } & 1 & 441 & 345.3 & 328.4 & 16.9 & 0.038 & 95.1 \\
\hline & & 2 & 396 & 313.9 & 296.1 & 17.8 & 0.045 & 94.3 \\
\hline & & 3 & 512 & 261.7 & 245.5 & 16.2 & 0.032 & 93.8 \\
\hline & & 4 & 421 & 198.1 & 183.1 & 15 & 0.036 & 92.4 \\
\hline & & 5 & 334 & 159.4 & 145.1 & 14.3 & 0.043 & 91 \\
\hline & & & & & & Average & 0.04 & 93.32 \\
\hline & \multirow[t]{6}{*}{ Second } & 1 & 530 & 332.1 & 314.7 & 17.4 & 0.03 & 94.7 \\
\hline & & 2 & 445 & 298.5 & 265.4 & 33.1 & 0 & 88.9 \\
\hline & & 3 & 396 & 273.3 & 241.4 & 31.9 & 0.06 & 88.3 \\
\hline & & 4 & 390 & 193.3 & 158.1 & 35.2 & 0.06 & 81.8 \\
\hline & & 5 & 369 & 159.1 & 130.5 & 28.6 & 0.08 & 82 \\
\hline & & & & & & Average & 0.05 & 87.14 \\
\hline \multirow{8}{*}{$\begin{array}{l}\text { Unlined } \\
\text { Canal }\end{array}$} & \multirow[t]{4}{*}{ First } & 1 & 245 & 148.3 & 135 & 18.6 & 0.1 & 91 \\
\hline & & 2 & 196 & 139.2 & 125.8 & 19.3 & 0.1 & 90 \\
\hline & & 3 & 128 & 130.9 & 114.3 & 21.6 & 0.2 & 87 \\
\hline & & & & & & Average & 0.13 & 89.33 \\
\hline & \multirow[t]{4}{*}{ Second } & 1 & 236 & 146 & 119.3 & 26.7 & 0.11 & 81.70 \\
\hline & & 2 & 194 & 133.6 & 110.3 & 23.3 & 0.12 & 82.6 \\
\hline & & 3 & 121 & 128 & 107.1 & 20.9 & 0.173 & 83.7 \\
\hline & & & & & & Average & 0.14 & 82.67 \\
\hline \multicolumn{9}{|c|}{ Fesas Irrigation Scheme } \\
\hline \multirow{3}{*}{$\begin{array}{l}\text { Lined } \\
\text { Canal }\end{array}$} & \multirow[t]{3}{*}{ First } & 1 & 386 & 301.3 & 293.3 & 8 & 0.02 & 97.4 \\
\hline & & 2 & 367 & 267.7 & 259.1 & 8.6 & 0.02 & 96.8 \\
\hline & & 3 & 298 & 234.3 & 225.2 & 9.1 & 0.03 & 96.1 \\
\hline
\end{tabular}

Note: Pd, Cl, and Ce are partial distance, conveyance loss, and conveyance efficiency respectively. 


\begin{tabular}{|c|c|c|c|c|c|c|c|c|}
\hline & & 4 & 401 & 168.2 & 161.1 & 7.2 & 0.02 & 95.7 \\
\hline & & 5 & 321 & 131.9 & 120.6 & 11.3 & 0.04 & 91.4 \\
\hline & & & & & & Average & 0.03 & 95.48 \\
\hline & Second & 1 & 513 & 320.6 & 311 & 9.7 & 0.019 & 97 \\
\hline & & 2 & 420 & 269.5 & 252.7 & 16.8 & 0.04 & 93.8 \\
\hline & & 3 & 413 & 234.3 & 211.5 & 22.8 & 0.055 & 90.3 \\
\hline & & 4 & 330 & 182.2 & 158.2 & 23.9 & 0.072 & 86.9 \\
\hline & & 5 & 310 & 122.3 & 89.8 & 32.5 & 0.105 & 73.4 \\
\hline & & & & & & Average & 0.06 & 88.28 \\
\hline Unlined & First & 1 & 212 & 119.7 & 107.2 & 12.5 & 0.06 & 89.5 \\
\hline & & 2 & 194 & 111.8 & 99.6 & 12.1 & 0.06 & 89.2 \\
\hline & & 3 & 120 & 101.6 & 89.6 & 12 & 0.1 & 88.2 \\
\hline & & & & & & Average & 0.07 & 88.97 \\
\hline & Second & 1 & 213 & 113.3 & 97.3 & 16 & 0.075 & 85.9 \\
\hline & & 2 & 193 & 105.3 & 87.4 & 17.9 & 0.093 & 83 \\
\hline & & 3 & 125 & 99.9 & 83.1 & 16.7 & 0.134 & 83.2 \\
\hline & & & & & & Average & 0.10 & 84.03 \\
\hline
\end{tabular}

The average application efficiency at the head, middle, and tail of Mugie SSI, respectively, was found $53 \%$, $54 \%$, and $60 \%$ during the first irrigation season and $59 \%, 54 \%, 54 \%$ during the second irrigation season with an overall application efficiency of $56 \%$ (Table 6). On the other hand, the average application efficiency at the head, middle, and tail of Fesas, respectively, was found $55 \%, 59 \%$, and $62 \%$ during the first irrigation season and $50 \%, 54 \%$, and $56 \%$ during the second irrigation season with an overall application efficiency of $54 \%$. Savva and Frenken, (2001) reported 50 to $70 \%$ as a recommended application efficiency for properly designed furrow irrigation. Similarly, Jurriëns and Lenselink, (2001) reported an application efficiency of $70 \%$ for furrow irrigation. Thus, the application efficiency of the Mugie and Fesa irrigation schemes was found within the recommended values. The amount of water delivered to the field in Mugie SSI during the first season irrigation across the growth stage of crops were varying from 48 to $54 \mathrm{~mm}$ at head users, 42 to $48 \mathrm{~mm}$ at middle users, and 44 to $54 \mathrm{~mm}$ at tail users. On the other hand, in Fesas irrigation schemes, the amount of water delivered to the field was in the order of 49 to $71 \mathrm{~mm}$ at head users, 70 to $73 \mathrm{~mm}$ at middle users, and 50 to $60 \mathrm{~mm}$ at tail users (Table 6). The application efficiency at head users of Mugie irrigation schemes was $48.8 \%$ for first irrigation season and $45.8 \%$ during second 
season irrigation at initial stage which is low based on the recommendation given by Savva and Frenken, (2001b). This indicated that the irrigation scheme was not properly managed for efficient field water delivery.

Table 6

Application efficiency per cropping season at the different crop growth stages.

\section{Mugie small scale irrigation}

\begin{tabular}{|c|c|c|c|c|c|c|c|c|c|c|}
\hline \multirow[b]{2}{*}{ Seasons } & \multirow[b]{2}{*}{ Stages } & \multicolumn{2}{|l|}{ Head } & \multicolumn{2}{|c|}{ Middle } & \multicolumn{2}{|l|}{ Tail } & \multirow{2}{*}{$\begin{array}{l}\text { Head } \\
\mathrm{Ea} \\
(\%)\end{array}$} & \multirow{2}{*}{$\begin{array}{l}\text { Middle } \\
\text { Ea }\end{array}$} & \multirow{2}{*}{$\begin{array}{l}\text { Tail } \\
\text { Ea }\end{array}$} \\
\hline & & Wf & Ws & Wf & Ws & Wf & Ws & & & \\
\hline & $\leftarrow \mathrm{mm} \rightarrow$ & & & & & & & $\leftarrow \%-$ & & \\
\hline \multirow[t]{4}{*}{ Season I } & Initial & 48.1 & 23.47 & 42.2 & 21.94 & 44.1 & 27.12 & 48.8 & 52 & 61.5 \\
\hline & Development & 54.2 & 28.88 & 48.5 & 28.86 & 53.5 & 32.47 & 53.3 & 59.5 & 60.7 \\
\hline & Late & 47.6 & 27.13 & 45.4 & 23.51 & 48.8 & 28.3 & 57 & 51.8 & 58 \\
\hline & Average & & & & & & & 53 & 54.4 & 60.1 \\
\hline \multirow{4}{*}{$\begin{array}{l}\text { Season } \\
\|\end{array}$} & Initial & 55.3 & 25.33 & 51.9 & 37.5 & 54.9 & 30.36 & 45.8 & 52.2 & 55.3 \\
\hline & Development & 49.9 & 29.24 & 47.7 & 45 & 46.5 & 21.29 & 58.6 & 57.9 & 45.8 \\
\hline & Late & 43.6 & 32.22 & 49.7 & 35.6 & 47.5 & 29.31 & 73.9 & 51.1 & 61.7 \\
\hline & Average & & & & & & & 59.4 & 53.7 & 54.3 \\
\hline
\end{tabular}

\section{Fesas small scale irrigation}

\begin{tabular}{lllllllllll} 
Season I & Initial & 71.1 & 39 & 72.9 & 41.4 & 70.5 & 41.9 & 55.2 & 56.8 & 59.2 \\
\cline { 2 - 10 } & Development & 70.6 & 35.5 & 72.3 & 39.9 & 59.6 & 38 & 50.4 & 55.7 & 63.8 \\
\cline { 2 - 10 } & Late & 49.3 & 40.1 & 69.5 & 65.8 & 62 & 39.6 & 59.6 & 64 & 63.9 \\
\cline { 2 - 11 } & Average & & & & & & & 55.1 & 58.8 & 62.3 \\
\multirow{2}{\text{II}}{ Season } & Initial & 71.1 & 36.9 & 70.6 & 34.5 & 70.5 & 41 & 51.9 & 48.9 & 58.1 \\
\cline { 2 - 10 } & Development & 70.6 & 34.5 & 72.3 & 39.4 & 59.6 & 35.4 & 48.9 & 54.5 & 59.4 \\
& Late & 80.3 & 40.1 & 69.5 & 40.6 & 76 & 39 & 49.9 & 58.4 & 51.3 \\
& Average & & & & & & & 50.2 & 53.9 & 56.3
\end{tabular}

Note: Wf, Ws, and Ea are water delivered to the field, water stored in the root zone, and application efficiency, respectively.

The product of conveyance efficiency and application efficiency provides the overall efficiency of the irrigation schemes, which were $51 \%$ and $50 \%$ for Mugie and Fesas SSI, respectively. The result indicated that the overall efficiency of Mugie was slightly higher than Fesas and within the range of $40-50 \%$, which 
is commonly observed in other similar African irrigation schemes (Savva and Frenken, 2001a). The storage efficiency relates to the amount of water needed before irrigation and the amount of water storage in the root zone during irrigation. It is a function of field capacity, permanent wilting point, and root depth of a crop where in this study we found at the $75 \%$ moisture depletion level (Muluneh et al., 2017). The average storage efficiency at Mugie SSI ranged from 47-56\% during the first irrigation season and 44$56 \%$ during the second season (Table 7). On the other hand, the average storage efficiency of Fesas SSI ranged from 56 to $58 \%$ during the first irrigation season and $52-59 \%$ during the second irrigation season. This finding is consistent with the recommendation given in Dayer et al., (2018) with the average water storage efficiency of furrow irrigation in the range of $50-55 \%$. 
Table 7

Storage efficiency per cropping season at the different crop growth stages.

Mugie small scale irrigation

\begin{tabular}{|c|c|c|c|c|c|c|c|c|c|c|}
\hline \multirow[b]{2}{*}{ Seasons } & \multirow[b]{2}{*}{ Stages } & \multicolumn{2}{|c|}{ Head } & \multicolumn{2}{|c|}{ Middle } & \multicolumn{2}{|l|}{ Tail } & \multirow{2}{*}{$\begin{array}{l}\text { Head } \\
\text { Es } \\
(\%)\end{array}$} & \multirow{2}{*}{$\begin{array}{l}\text { Middle } \\
\text { Es }\end{array}$} & \multirow{2}{*}{$\begin{array}{l}\text { Tail } \\
\text { Es }\end{array}$} \\
\hline & & Wn & Ws & Wn & Ws & $W f$ & Wn & & & \\
\hline & $\leftarrow \mathrm{mm} \rightarrow$ & & & & & & & $\leftarrow \% \rightarrow$ & & \\
\hline \multirow[t]{4}{*}{ Season I } & Initial & 82.5 & 47.7 & 68.3 & 37.8 & 85 & 44.8 & 48.4 & 55.2 & 52.1 \\
\hline & Development & 93.3 & 45 & 77 & 46.5 & 86.3 & 44.9 & 48.4 & 60.4 & 52.1 \\
\hline & Late & 89.5 & 38.2 & 74.5 & 38.7 & 92 & 44.9 & 42.8 & 52.1 & 49 \\
\hline & Average & & & & & & & 47 & 56 & 51 \\
\hline \multirow{4}{*}{$\begin{array}{l}\text { Season } \\
\text { II }\end{array}$} & Initial & 82.5 & 34.5 & 78 & 41.4 & 85 & 41.4 & 41.8 & 55 & 48.7 \\
\hline & Development & 93.3 & 46.8 & 78 & 39.9 & 86.3 & 41.7 & 50.2 & 58.4 & 48.3 \\
\hline & Late & 89.5 & 36.2 & 78 & 49.9 & 92 & 41.7 & 40.4 & 54.5 & 45.3 \\
\hline & Average & & & & & & & 44 & 56 & 47 \\
\hline \multicolumn{11}{|c|}{ Fesas small scale irrigation } \\
\hline \multirow[t]{4}{*}{ Season I } & Initial & 63.3 & 39 & 68.3 & 37.5 & 70.5 & 41.86 & 61.86 & 52.9 & 55.4 \\
\hline & Development & 66 & 35.5 & 77 & 45 & 82.5 & 38 & 53.7 & 51.2 & 45.9 \\
\hline & Late & 63.3 & 40 & 74.5 & 40.6 & 63.3 & 43 & 59.6 & 64 & 67.9 \\
\hline & Average & & & & & & & 58 & 56 & 56 \\
\hline \multirow{4}{*}{$\begin{array}{l}\text { Season } \\
\text { II }\end{array}$} & Initial & 63.3 & 36.9 & 78 & 39.6 & 81 & 41 & 58.4 & 50 & 50.6 \\
\hline & Development & 66 & 34.5 & 78 & 39.4 & 82.5 & 35.4 & 52.3 & 50 & 42.9 \\
\hline & Late & 63.3 & 40.1 & 78 & 40.6 & 63.3 & 39 & 65.4 & 62 & 61.66 \\
\hline & Average & & & & & & & 59 & 54 & 52 \\
\hline
\end{tabular}

\subsection{External Performance Indicators}

Total crop productivity of $187,700 \mathrm{~kg}$ was obtained at Mugie SSI from a gross crop area of 64 ha with a gross income of $85,811 \$$ whereas, at Fesas SSI crop productivity was $173900 \mathrm{~kg}$ from 52 ha crop area with a gross income of $74,176 \$$ (Table 8 ). In the actual circumstances, the design command area (82ha for Mugie and 75ha for Fesas) was not fully covered with crops due to a shortage of irrigation water as a result of poor water management and various losses. The total annual volume of irrigation water diverted 
during the dry season (October to June) was $384,073 \mathrm{~m}^{3}$ and $284,285 \mathrm{~m}^{3}$ for Mugie and Fesas irrigation schemes, respectively. The total amount of water consumed for irrigation in Mugie and Fesas irrigation schemes were $317,818.5 \mathrm{~m}^{3}$ and $231,800 \mathrm{~m}^{3}$ respectively. The amount of revenue collected per unit cultivated area was $1,340 \$ /$ ha and 1,426 $\$$ /ha, respectively, at Mugie and Fesas irrigation schemes. In the Fesas irrigation scheme the crop area was reduced by 12 ha than Mugie but with increased collected revenue due to the variation of input materials (such as fertilizers), efficient use of water, and effective overall management of schemes. This study revealed that income generation per unit command area at Mugie and Fesas irrigation schemes, respectively, were $1046 \$ /$ ha and $989 \$ /$ ha which indicates a reduction of income. 
Table 8

Income generation from small-scale irrigation schemes.

\section{Mugie irrigation Scheme}

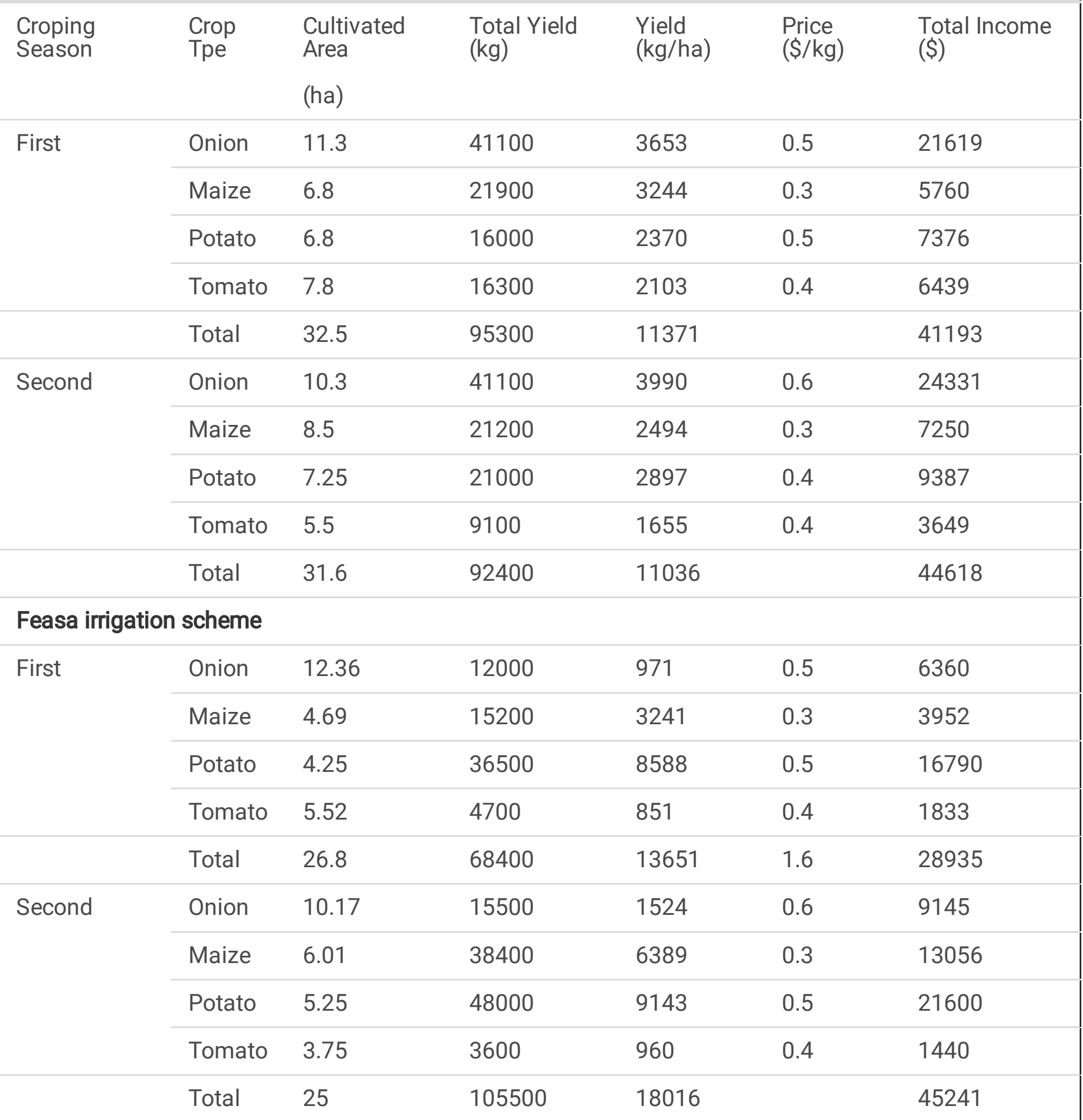

Note: kg refers to kilogram, $\$$ refers to the dollar, and ha refers to hectare.

The amount of revenue for the Mugie scheme per unit volume of water consumed was $0.27 \$ / \mathrm{m}^{3}$. A slight increment was observed in Fesas schemes $\left(0.32 \$ / \mathrm{m}^{3}\right)$. The result showed $0.22 \$ / \mathrm{m}^{3}$ and $0.26 \$ / \mathrm{m}^{3}$ revenue from a unit volume of diverted irrigation water for Mugie and Fesas irrigation schemes, 
respectively. In Fesas SSI, farmers were practicing deficit irrigation with efficient water application whereas, over-irrigation was practiced in Mugie SSI. This shows that agricultural performance in Fesas SSI was found relatively higher as compared with Mugie SSI. On the other hand, the relative water supply (ratio) was 3.17 and 2.45 for Mugie and Fesas SSI, respectively, which shows poor management (overirrigation). The relative irrigation supply was 1.23 for Mugie and 0.94 for Fesas SSI indicating the practice of deficit irrigation in Fesas as compared to Mugie, however, it does not mean the crop is stressed. Uysal and Atiş, (2010) reported a relative irrigation supply in the range of 0.41 to 4.81 on a world scale. The lowest value (0.41) was associated with deficit irrigation and the larger value (4.81) value was associated with full irrigation supply. Based on this, the result found an ideal water supply and relative irrigation supply values for both Mugie and Fesas irrigation schemes.

Table 9, the relative irrigation, and water supply with irrigation ratio were reported by different researchers in various regions of Ethiopia. In the Amhara region, the relative water supply and relative irrigation supply were much higher than one indicating excess supply of water beyond the crop water need. However, the irrigation ratio is reported far below one indicating lower cropped area coverage. Therefore, our finding indicated a comparative water-saving than the reported schemes in the Amhara region. Similarly, the physical performance indicator was improved than the Amhara region (Table 9). The ratio of irrigable area to the command area (i.e., irrigation ratio) was found 0.78 (i.e., $78 \%$ of the command area was under irrigation) for the Mugie irrigation scheme and 0.69 (69\% of the command was irrigated) in Fesas irrigation scheme. This finding is comparable with the irrigation ratio of the Southern nation national people of Ethiopia (SNNPE). The irrigation ratio of schemes in the Oromia and Tigray regions was reported more than $90 \%$ (Table 9). The topographic nature of the Fesas river catchment limited the gravitational flow of water to the command and as a result, water shortage was regarded as a major limitation during irrigation practice. 
Table 9

Regional command area coverage by irrigation and water supply distribution among selected schemes in Ethiopia.

\begin{tabular}{|c|c|c|c|c|c|}
\hline Name of SSI & Region & $\operatorname{IR}(\%)$ & RWS & RIS & Reporter \\
\hline Wosha & \multirow[t]{2}{*}{ SNNPE } & 89 & 0.71 & 0.64 & \\
\hline Werka & & 78 & 0.55 & 0.48 & (Tesfaye et al., 2019) \\
\hline Ashar & \multirow[t]{5}{*}{ Amhara } & 4.55 & 6.21 & 6.62 & (Adane, 2020) \\
\hline Zuma-I & & 30 & 4.11 & 5.17 & \\
\hline Quashine & & 14 & 5.23 & 5.73 & \\
\hline Zuma-II & & 10 & 3.56 & 3.6 & \\
\hline Shina-Hamusit & & 40 & 1.55 & 1.31 & (Shenkut, 2015) \\
\hline Haleku & \multirow[t]{2}{*}{ Oromia } & 100 & 3.34 & 2.89 & \\
\hline Dodicha & & 59 & 3.34 & 2.89 & (Woreda et al., 2019) \\
\hline Tsalit & Tigray & 91 & - & - & (Efriem and Mekonen, 2017) \\
\hline
\end{tabular}

The gross return on investment for Mugie and Fesas schemes was found to be 0.42 (i.e., $42 \%$ ) and 0.51 (i.e., 51\%), respectively. In terms of financial performance indicators, the cost of infrastructure was found more than the amount of revenue collected from the Mugie irrigation scheme. Whereas nearly half of the cost of infrastructure was compensated from the amount of income collected in the Fesas irrigation scheme.

\section{Challenges And Remedial Measures For Ssi}

Several research findings depicted that SSI plays a significant role in adapting to climate change, achieving food security, and improving household income. However, several limitations are affecting the success of SSI. Awulachew and Ayana, (2011) pointed out various limitations constraining the success of SSI: inadequate irrigation water management, lack of capacity for regular maintenance and weak institutional arrangement, sedimentation of weirs and canals, poor crop choice and inefficient cropping system, lack of interest in schemes, water right conflict among users, market problem, main canal seepage, damage to the infrastructure, crop disease, and illegal water abstraction.

Therefore, to improve the performance of irrigation schemes integrated management of water and soil should be done. Training on water management on the farm level and throughout the irrigation scheme should be given to the farmers. Water-saving techniques like conservation agricultural water management practice and low-cost drip irrigation techniques could help in maximizing water use efficiency. Strong institutional support and arrangement should also be needed to facilitate and support the farmers in terms 
of supplying quality seed and creating a market chain with the local trade union. Strong follow-up on crop choice and cropping pattern should be given by the agricultural expertise to improve water use efficiency and the interest of farmers towards irrigation. Regularly follow up of the schemes should be done through the institution, for example, deposited debris and sediments along the main canal which is the main cause of water loss. Regular maintenance should be done to improve the conveyance efficiency of schemes for example non-functionality of operating gates, breach of the main canal due to erosion. The result from this study depicted that, various remedial actions need to be considered to operate Mugie and Fesas SSI fully, for the designed command area. This includes regular maintenance of the scheme, improving water management among farmers, removing excess accumulated sediment and boulders on the main canal, minimizing canal seepage through grouting, changing, and maintaining unfunctional gates along the main canal, and river training work to avoid loss of irrigated area due to erosion during the rainy season because of the meandering nature of the river course.

\section{Conclusion}

In this study, we evaluated the performance of two small-scale irrigation (SSI) schemes in northern Ethiopia, Mugie and Fesas. Both internal (conveyance, application, and storage efficiency) and external (agricultural, water supply, physical and financial performance indicators) indicators were considered in evaluating the SSI. The bulk density of the soils was ranging from 1 to $1.2 \mathrm{gmcm}^{-3}$ which shows the suitability of land for crop growth. The maximum water holding capacities of the soil for both schemes were up to $38 \%$ during full water supply. Under stressed conditions at wilting point minimum water holding capacity of $13 \%$ was observed. Across the scheme, to meet the crop water need from the irrigation supply, $100 \mathrm{~mm}$ to $250 \mathrm{~mm}$ of water need to be stored in the soil. In the lined main canal, the conveyance efficiency was found $90 \%$ and $92 \%$, respectively, for Mugie and Fesas irrigation schemes, which is below the standard (95\%). A lower conveyance efficiency at Mugie was due to water loss through seepage, overtopping, and leakage of the main canal. Overall performance of the two small-scale irrigation schemes was found close to $50 \%$, depicting a low performance which was not associated with the amount of water supply but rather was due to poor management of the scheme in general. The result from water supply indicators showed that throughout the crop base period, the water availability was more than the crop water requirement. For Mugie small-scale irrigation scheme, both the relative irrigation and water supply indicators were more than one which indicates over-irrigation. Whereas in the Fesas irrigation scheme, a slightly lower value of irrigation water supply was found indicating deficit irrigation practice. In this study, we found that the Mugie irrigation scheme performed better than the Fesas based on gross (overall) efficiency rating. However, improvement measures are needed for both Mugie and Fesas irrigation schemes. The canal should be free from any silt deposition and boulder accumulation to avoid overtopping over the main canal. Besides, farm water management practices need to be improved by the farmers. Institutional support is vital to improve and maintain the failure of infrastructures for better performance.

\section{Declarations}


Ethics approval and consent to participate: Not applicable.

Consent for publication: Not applicable.

Availability of data and materials. The datapresented in this study is available on request from the corresponding author.

Competing interest: The authors declare no conflict of interest.

Funding: Not applicable.

Author contribution.A.M.B contributed to data collection, analysis, and draft the manuscript; T.T.A. contributed to the experimental design, data acquisition, analysis, interpretation, and revised the manuscript for the scientific content; S.A.B. contributed to data analysis and interpretation and revised the manuscript, and A.Y.Y. contributed to data analysis and interpretation and revising the manuscript.

Acknowledgments. We would like to acknowledge the Ethiopian National Metrological Agency (ENMA) for providing quality data for this research.

\section{References}

1. Abiyu, A., 2016. Challenges and Opportunities of Small-Scale Irrigation Utilization in Rift Valley Basin, Humbo Woreda, Ethiopia. J. Econ. Sustain. Dev. www.iiste.org ISSN 7.

2. Abraham, A., 2009. Agricultural biotechnology research and development in Ethiopia. African J. Biotechnol. https://doi.org/10.5897/AJB2009.000-9553

3. Adane, B., 2020. Performance Assessment of Small-Scale Irrigation Schemes: A Case Study of Upper Blue Nile, East Dangila 9, 7-10. https://doi.org/10.37421/idse.2020.9.247

4. Adela, F.A., Aurbacher, J., Abebe, G.K., 2019. Small-scale irrigation scheme governance - poverty nexus: evidence from Ethiopia. Food Security. 11. https://doi.org/10.1007/s12571-019-00953-8

5. Agide Dejen, Z., 2012. Comparative irrigation performance assessment in community-managed schemes in Ethiopia. African J. Agric. Research 7, 4956-4970. https://doi.org/10.5897/ajar11.2135

6. Ahmed, B., 2017. Bayan Ahmed Technical Performance Evaluation of Mada Batu Small Scale Irrigation Scheme, West Arsi Zone of Oromia Region. Int. J. Eng. Res. 5.

7. Akkuzu, E., Ünal, H.B., Karataş, B.S., 2007. Determination of water conveyance loss in the Menemen open canal irrigation network. Turkish J. Agric. For. 31. https://doi.org/10.3906/tar-0611-10

8. Al-Said, F.A., Ashfaq, M., Al-Barhi, M., Hanjra, M.A., Khan, I.A., 2012. Water productivity of vegetables under modern irrigation methods in Oman. Irrig. Drain. 61. https://doi.org/10.1002/ird.1644

9. Alebachew, S., Ing, P.S., 2018. Evaluation of canal water conveyance and on-farm water application for a small-scale irrigation scheme in Ethiopia. Int. J. Water Resour. Environ. Eng. 10, 100-110. https://doi.org/10.5897/ijwree2018.0800 
10. Alemu, M.M., 2017. Agricultural Extension for Enhancing Production and Productivity: The Case of Southern Ethiopia, Arba Minch Zuriya District. OALib 04. https://doi.org/10.4236/oalib.1103427

11. Amede, T., 2015. Technical and institutional attributes constraining the performance of small-scale irrigation in Ethiopia. Water Resour. Rural Dev. 6, 78-91.

12. Amer, A.M., Amer, K.H., 2010. Surface irrigation management concerning water infiltration and distribution in soils. Soil Water Res. 5. https://doi.org/10.17221/47/2009-swr

13. Aseyehegu, K., Yirga, C., Rajan, S., 2012. Effect of Small-Scale Irrigation on The Income of Rural Farm Households: The Case Of Laelay Maichew District, Central Tigray, Ethiopia. J. Agric. Sci. 7, 43. https://doi.org/10.4038/jas.v7i1.4066

14. Asmamaw, M., 2015. The resilience of Ecosystems to Climate Change. Am. J. Environ. Prot. 4. https://doi.org/10.11648/j.ajep.20150406.19

15. Awulachew, S.B., Ayana, M., 2011. Performance OF irrigation: An assessment at different scales in Ethiopia. Exp. Agric. 47, 57-69. https://doi.org/10.1017/S0014479710000955

16. Boke, A.S., 2017. Comparative Evaluation of Spatial Interpolation Methods for Estimation of Missing Meteorological Variables over Ethiopia. J. Water Resour. Prot. 09. https://doi.org/10.4236/jwarp.2017.98063

17. Bossio, D., Erkossa, T., Dile, Y., McCartney, M., Killiches, F., Hoff, H., 2012. Water implications of foreign direct investment in Ethiopia's agricultural sector. Water Altern. 5.

18. Bumbudsanpharoke, W., Prajamwong, S., 2015. Performance assessment for irrigation water management: A case study of the great chao phraya irrigation scheme. Irrig. Drain. 64. https://doi.org/10.1002/ird.1889

19. Checkol, G., Alamirew, T., 2008. Technical and institutional evaluation of geray irrigation scheme in West Gojjam Zone, Amhara Region, Ethiopia. J. Spat. Hydrol. 8.

20. da Silva, G.H., Ferreira, M.G., Pereira, S.B., Delazari, F.T., da Silva, D.J.H., 2017. The response of bell pepper crop subjected to irrigation depths calculated by different methodologies. Rev. Bras. Eng. Agric. e Ambient. 22. https://doi.org/10.1590/1807-1929/agriambi.v22n1p45-50

21. Dayer, E., Pazira, E., Kashkuli, H.A., Sedghi, H., 2018. Changing Furrow Irrigation to Increase Efficiency and Feasibility Study of Reusing Surface Runoff. Civ. Eng. J. 3. https://doi.org/10.28991/cej-030957

22. De Alwis, S.M.D.L.K., Wijesekera, N.T.S., 2011. Comparison of Performance Assessment Indicators for Evaluation of Irrigation Scheme Performances in Sri Lanka. Eng. J. Inst. Eng. Sri Lanka 44. https://doi.org/10.4038/engineer.v44i3.6963

23. Degirmenci, H., Büyükcangaz, H., Merdun, H., 2006. Assessment of irrigation schemes in Turkey with irrigation ratio and relative water supply. Water Int. https://doi.org/10.1080/02508060.2006.9709676

24. Değirmenci, H., Tanriverdi, Ç., Arslan, F., Gönen, E., 2017. BENCHMARKING PERFORMANCE OF LARGE SCALE IRRIGATION SCHEMES WITH COMPARATIVE INDICATORS IN TURKEY. Sci. Pap. Ser. E. L. Reclam. Earth Obs. Surv. Environ. Eng. VI.

25. Dessalew, T., Ayalew, A., Desalegn, T., Mathewos, M., Alemu, G., 2016. Performance Evaluation of Bedene Alemtena Small Scale Irrigation Scheme in Hallaba Special Woreda, Southern Ethiopia. OALib 
03. https://doi.org/10.4236/oalib.1102021

26. Efriem, T.K., Mekonen, A., 2017. Hydraulic performance assessment of Tahtay Tsalit small-scale irrigation scheme, Tigray, Ethiopia. Int. J. Water Resour. Environ. Eng. 9, 254-263. https://doi.org/10.5897/ijwree2017.0728

27. Eggen, M., Ozdogan, M., Zaitchik, B.F., Simane, B., 2016. Land cover classification in complex and fragmented agricultural landscapes of the Ethiopian highlands. Remote Sens. 8. https://doi.org/10.3390/rs8121020

28. Fontenelli, J.V., da Silva, T.J.A., Bonfim-Silva, E.M., Sousa, H.H.F., Duarte, T.F., Koetz, M., 2017. Methods of soil moisture maintenance for production of sunflower under controlled conditions. Aust. J. Crop Sci. 11. https://doi.org/10.21475/ajcs.17.11.05.p405

29. Gebregziabher, G., Namara, R.E., Holden, S., 2009. Poverty reduction with irrigation investment: An empirical case study from Tigray, Ethiopia. Agric. Water Manag. 96. https://doi.org/10.1016/j.agwat.2009.08.004

30. Gebresenbet, T.S., 2015. Modeling of Cascade Dams and Reservoirs Operation for Optimal Water Use: Application to Omo Gibe River Basin, Ethiopia. Univ. Kassel.

31. Gebru, T.D., 2016. Deforestation in Ethiopia: causes, impacts, and remedy. Int. J. Eng. Dev. Res. 4.

32. Hagos, F., Makombe, G., Namara, R.., Awulachev, S.., 2011. Importance of irrigated agriculture to the Ethiopian economy. Ethiop. J. Dev. Res. 127-155.

33. Imhoff, S., Da Silva, A.P., Ghiberto, P.J., Tormena, C.A., Pilatti, M.A., Libardi, P.L., 2016. Physical quality indicators and mechanical behavior of agricultural soils of Argentina. PLoS One 11. https://doi.org/10.1371/journal.pone.0153827

34. Jabro, J.D., Stevens, W.B., Iversen, W.M., Allen, B.L., Sainju, U.M., 2020. Irrigation scheduling based on wireless sensors output and soil-water characteristic curve in two soils. Sensors (Switzerland) 20. https://doi.org/10.3390/s20051336

35. Jurriëns, M., Lenselink, K.J., 2001. Straightforward furrow irrigation can be $70 \%$ efficient. Irrig. Drain. 50. https://doi.org/10.1002/ird.7

36. Kartal, S., Değirmenci, H., Arslan, F., 2020. Assessment of irrigation schemes with performance indicators in a southeastern irrigation district of Turkey. Tarim Bilim. Derg. 26, 138-146. https://doi.org/10.15832/ankutbd.512677

37. Kassa, E.T., Ayana, M., 2019. Hydraulic Performance Assessment of Mychew Small Scale Irrigation Scheme, North Ethiopia. Int. J. Environ. Clim. Chang. 9, 549-561.

https://doi.org/10.9734/ijecc/2019/v9i1030139

38. Kifle, M., Tilahun, K., Yazew, E., 2008. Evaluation of surge flow furrow irrigation for onion production in a semiarid region of Ethiopia. Irrig. Sci. 26. https://doi.org/10.1007/s00271-007-0096-6

39. Kindu, B., 2019. Smallholder Farmer's Adaptation Strategy to Climate Change in The Case of Este Woreda, South Gondar Zone, Amhara Region, Ethiopia. World J. Agric. Soil Sci. 3. https://doi.org/10.33552/wjass.2019.03.000551 
40. Kortenhorst, L.F., van Steekelenburg, P.N.G., Sprey, L.H., 1989. Prospects and problems of irrigation development in Sahelian and sub-Saharan Africa. Irrig. Drain. Syst. 3.

https://doi.org/10.1007/BF01102814

41. Mahapatra, S., Jha, M.K., Biswal, S., Senapati, D., 2020. Assessing Variability of Infiltration Characteristics and Reliability of Infiltration Models in a Tropical Sub-humid Region of India. Sci. Rep. 10. https://doi.org/10.1038/s41598-020-58333-8

42. Makombe, G., Namara, R.E., Awulachew, S.B., Hagos, F., Ayana, M., Kanjere, M., 2017. An analysis of the productivity and technical efficiency of smallholder irrigation in Ethiopia. Water SA 43. https://doi.org/10.4314/wsa.v43i1.08

43. Molden, D., Sakthivadivel, R., Perry, C., de Fraiture, C., Kloezen, W., 1998. Indicators for comparing the performance of irrigated agricultural systems, Research Report.

44. Muluneh, A., Stroosnijder, L., Keesstra, S., Biazin, B., 2017. Adapting to climate change for food security in the Rift Valley dry lands of Ethiopia: Supplemental irrigation, plant density, and sowing date. J. Agric. Sci. 155. https://doi.org/10.1017/S0021859616000897

45. Ngigi, S.N., 2003. What is the limit of up-scaling rainwater harvesting in a river basin? Phys. Chem. Earth 28. https://doi.org/10.1016/j.pce.2003.08.015

46. Savva, A.P., Frenken, K., 2001a. Irrigation Manual Planning, development Monitoring and evaluation of irrigated agriculture with farmer participation III, Planning, Development Monitoring and Evaluation of Irrigated Agriculture with Farmer Participation.

47. Savva, A.P., Frenken, K., 2001b. Irrigation Manual, Planning, Development Monitoring and Evaluation of Irrigated Agriculture with Farmer Participation.

48. Sener, M., Albut, S., 2011. Irrigation performance assessment in Turkey: Thrace region case study. Bulg. J. Agric. Sci. 17, 521-530.

49. Shenkut, A., 2015. to Comparative Indicators: A Case Study of Shina- 5, 451-460.

50. Tesfaye, A., Bogale, A., Namara, R.E., Bacha, D., 2008. The impact of small-scale irrigation on household food security: The case of Filtino and Godino irrigation schemes in Ethiopia. Irrig. Drain. Syst. 22. https://doi.org/10.1007/s10795-008-9047-5

51. Tesfaye, H., Dananto, M., Woldemichael, A., 2019. Comparative Performance Evaluation of Irrigation Schemes in Southern 8, 2-6. https://doi.org/10.4172/2168-9768.1000232

52. Uysal, Ö.K., Atiş, E., 2010. Assessing the performance of participatory irrigation management over time: A case study from Turkey. Agric. Water Manag. 97. https://doi.org/10.1016/j.agwat.2010.02.007

53. van Halsema, G.E., Keddi Lencha, B., Assefa, M., Hengsdijk, H., Wesseler, J., 2011. Performance assessment of smallholder irrigation in the central rift valley of Ethiopia. Irrig. Drain. 60, 622-634. https://doi.org/10.1002/ird.613

54. Wachyan, E., Rushton, K.R., 1987. Water losses from irrigation canals. J. Hydrol. 92, 275-288. https://doi.org/10.1016/0022-1694(87)90018-7

55. Woreda, J.K., Rift, C., Shiberu, E., Hk, H., Kibret, K., 2019. Irrigation \& Drainage Systems Engineering Comparative Evaluation of Small Scale Irrigation Schemes at Adami Tulu 8, 1-5. 
https://doi.org/10.4172/2168-9768.1000226

56. Xiao, Y., Wang, W., Hu, X., Wang, Y., 2015. Experiment on the hydraulic performance of short-throat flume with a flat base for field flow measurements. Shuili Fadian Xuebao/Journal Hydroelectric. Eng. 34. https://doi.org/10.11660/slfdxb.20151011

57. Xie, H., You, L., Dile, Y.T., Worqlul, A.W., Bizimana, J.C., Srinivasan, R., Richardson, J.W., Gerik, T., Clark, N., 2021. Mapping development potential of dry-season small-scale irrigation in Sub-Saharan African countries under joint biophysical and economic constraints - An agent-based modeling approach with an application to Ethiopia. Agric. Syst. 186, 102987. https://doi.org/10.1016/j.agsy.2020.102987

58. Zeweld, W., Huylenbroeck, G. Van, Hidgot, A., Chandrakanth, M.G., Speelman, S., 2015. Adoption of Small-Scale Irrigation and Its Livelihood Impacts in Northern Ethiopia. Irrig. Drain. 64. https://doi.org/10.1002/ird.1938

\section{Figures}




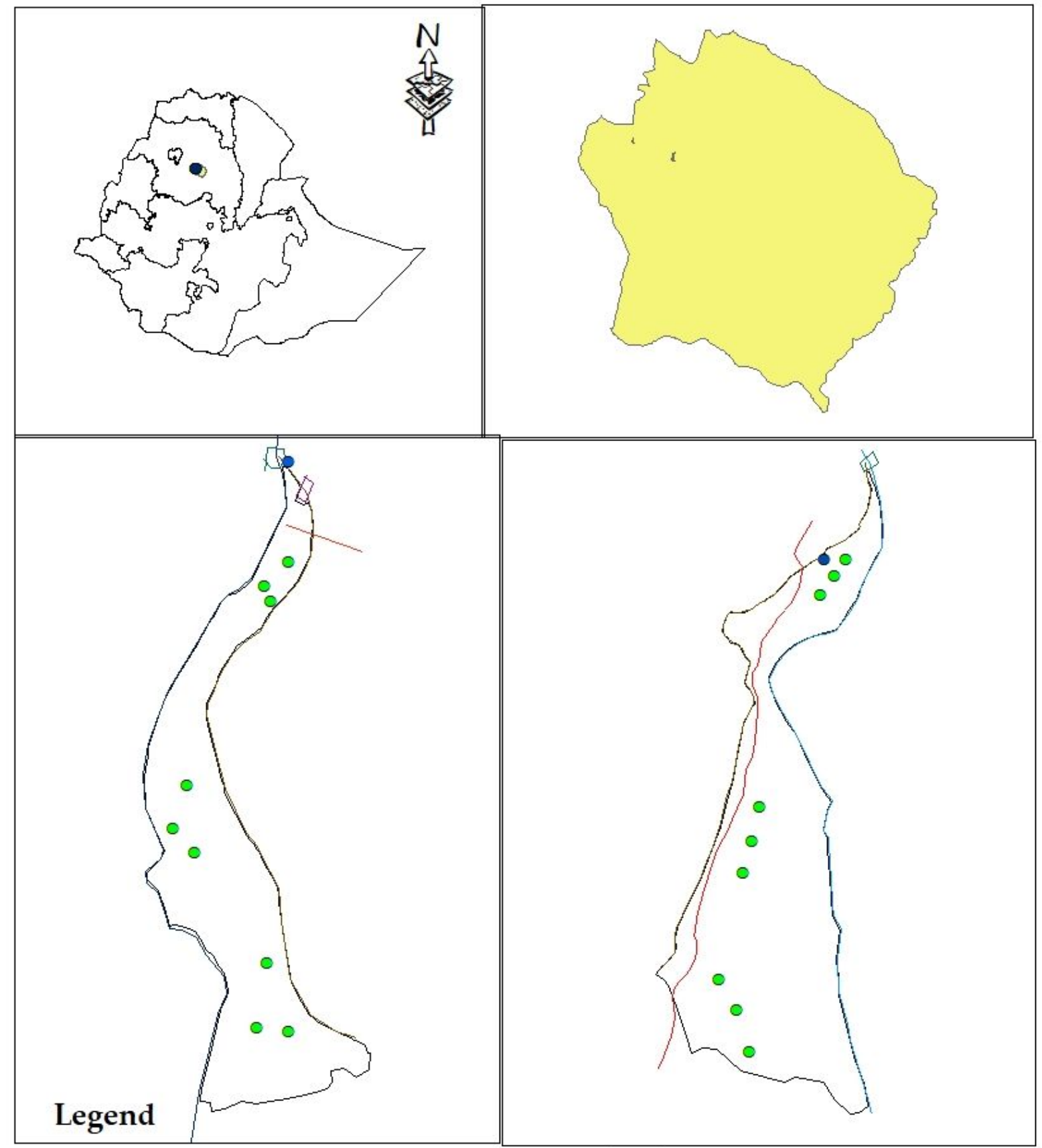

- River outlet Canal

- Soil sample location — Road

Aqueduct

Weir location

Ethiopia admistratives

Simada Worda

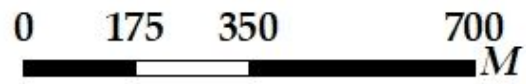

Figure 1

Location of Fesas and Mugie irrigation schemes and location of data monitoring sites 

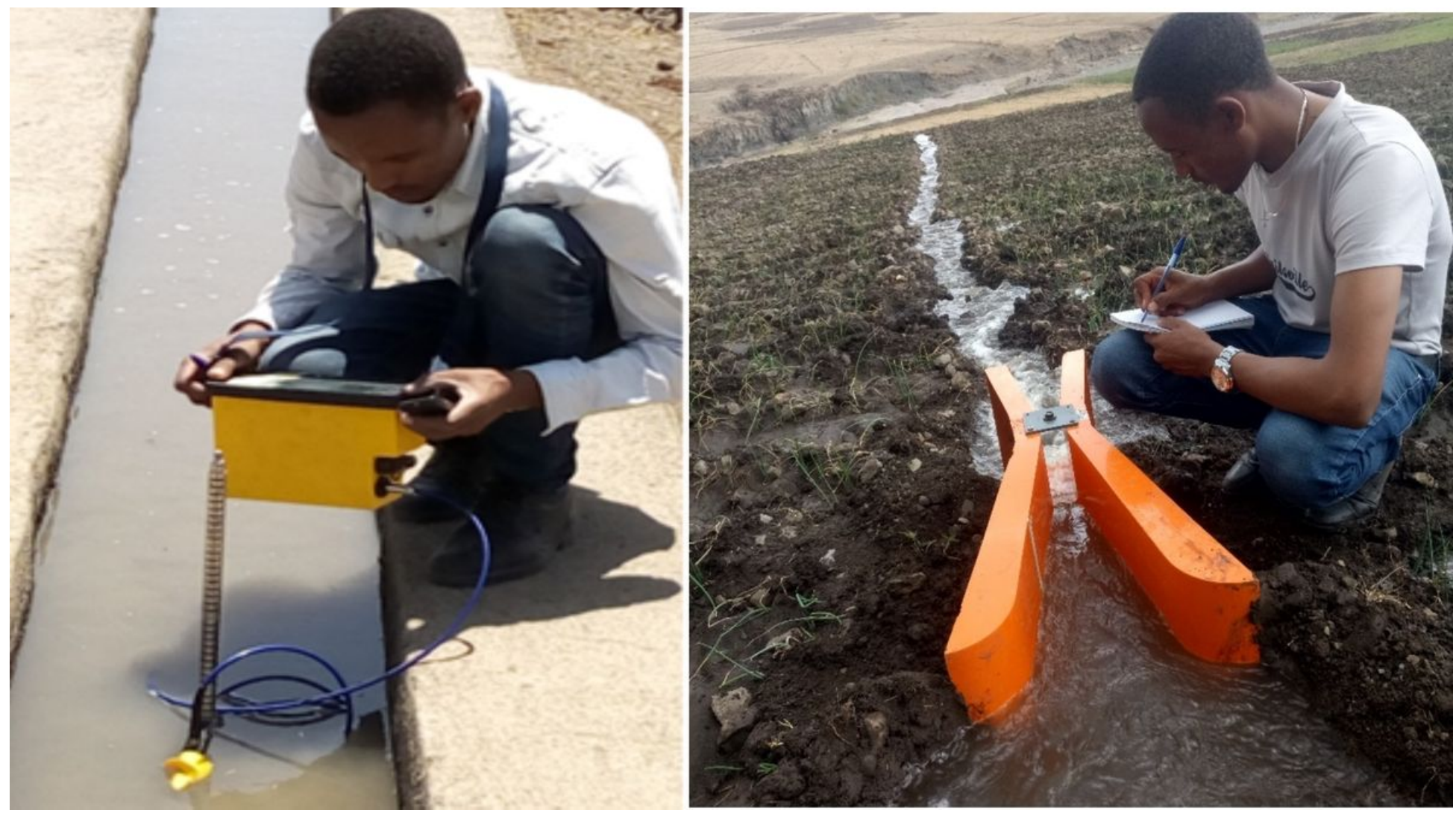

Figure 2

Measurement of water application at farm level using Partial flume (right) and average flow velocity measurement using current meter along the main canals (left). 

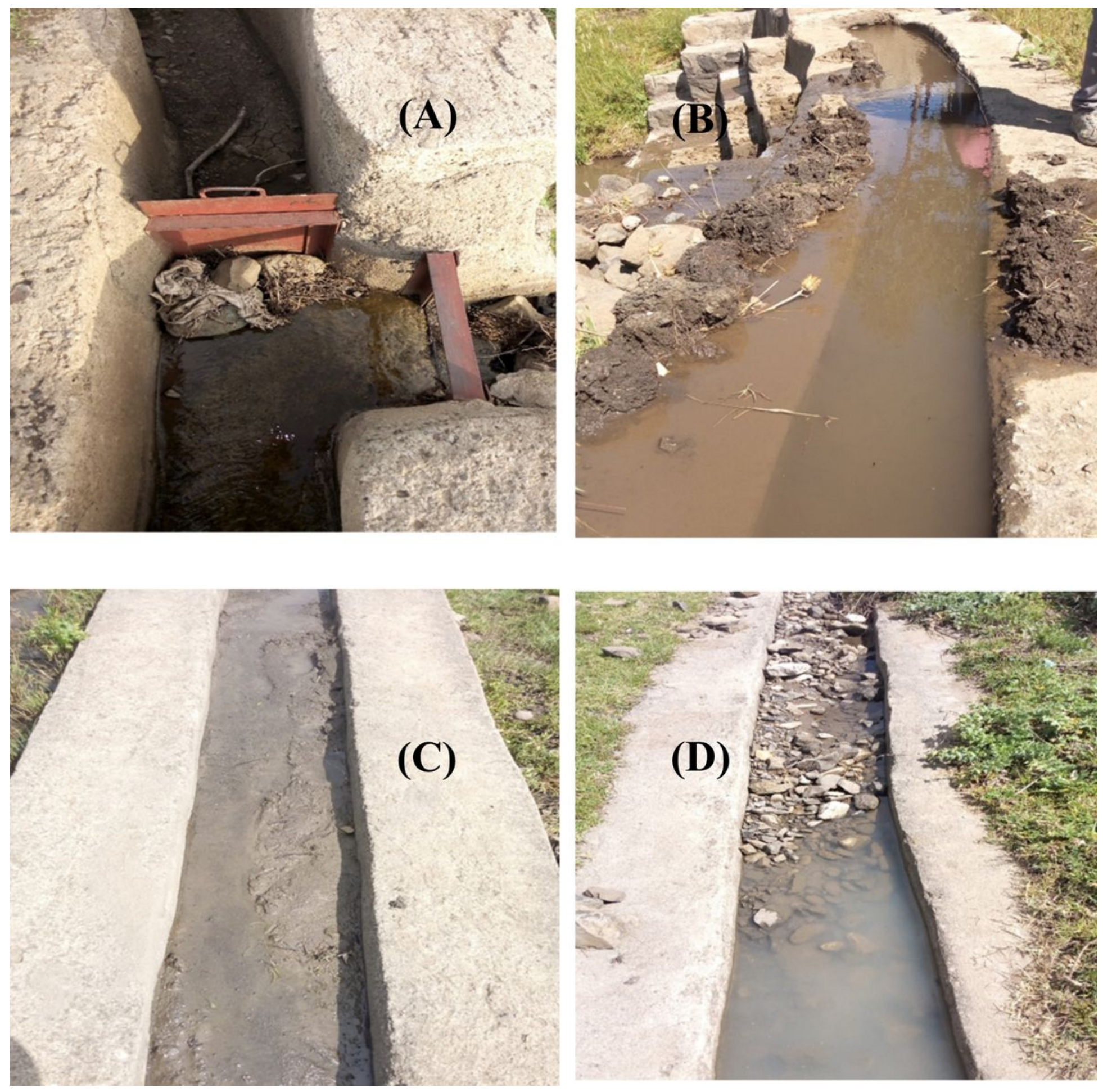

Figure 3

Performance of main canals during field investigation; malfunction of the gate in the main canal (A), loss of water due to overtopping over the main canal and high-water loss due to seepage (B), sediment deposition along the main canal (C), and boulder accumulation on the main canal bed (D). 